\title{
MANP: a novel particulate guanylyl cyclase A receptor/cGMP activator for resistant hypertension: preliminary first in human clinical trial results
}

\author{
John C. Burnett Jr*, Paul McKie, Denise Heublein, Brenda Huntley, Horng Chen, Valentina Cannone, \\ Alessia Buglioni, Daniel McCormick
}

From 7th International Conference on cGMP Generators, Effectors and Therapeutic Implications Trier, Germany. 19-21 June 2015

\section{Introduction}

MANP is a novel natriuretic peptide developed at the Mayo Clinic following its discovery from a familial frameshift mutation of the atrial natriuretic peptide (ANP) gene (NPPA) [1,2]. MANP possesses the 28 amino acid (AA) core structure of ANP with a novel 12 AA extended Cterminus resulting in a 40 AA peptide. MANP activates the particulate guanylyl cyclase A (pGC-A) receptor with equal potency to ANP and is highly resistant to degradation by neprilysin. In vivo, MANP has greater and longer lasting blood pressure (BP) lowering, natriuretic and aldosterone suppressing actions than ANP [3]. In animal models of hypertension, MANP potently reduces BP and enhances renal function while in experimental hypertensive heart failure, MANP has more potent renal and aldosterone suppressing actions than the cyclic guanylyl monophosphate (cGMP)-activating therapeutic agent nitroglycerin [4]. In vivo administered subcutaneously, MANP activates plasma cGMP 10-fold greater than ANP with a 4-fold greater half-life [3,4]. Based upon its potent cGMP mediated cardiorenal actions and studies which suggest that human hypertension may represent a relative natriuretic peptide deficiency state, MANP is being developed for treatment of severe resistant hypertension.

\section{Methods and results}

MANP (ZD100, Zumbro Discovery) recently entered a first in human trial in patients with hypertension. A Phase

\footnotetext{
* Correspondence: burnett.john@mayo.edu

Cardiorenal Research Laboratory, Division of Cardiovascular Diseases, and Department of Biochemistry and Molecular Biology, Mayo Clinic, Rochester,
} MN 55905, USA

\section{Conclusion}

MANP is a novel, sustained-acting pGC/cGMP activating peptide, which goes beyond ANP in reducing BP, augmenting renal function and suppressing aldosterone. BP and safety data will be presented for the first time from the recently completed first in human SAD study in patients with hypertension.

Published: 2 September 2015

\section{References}

McKie P, Cataliotti A, Huntley B, Martin F, Olson T, Burnett JC Jr: A human atrial natriuretic peptide gene mutation reveals a novel peptide with enhanced blood pressure lowering, renal enhancing and aldosterone suppressing actions. J Am Coll Card 2009, 54:1024-1032.

2. Dickey DM, Yoder AR, Potter LR: A familial mutation render atrial natriuretic peptide resistant to proteolytic degradation. J Biol Chem 2009, 284:19196-202

3. McKie PM, Cataliotti A, Boerrigter G, Chen HH, Sangaralingham SJ, Martin FL, et al: A novel atrial natriuretic peptide based therapeutic in experimental angiotensin II mediated acute hypertension. Hypertension 56:1152-1159. 
4. McKie P, Cataliotti A, Ichiki T, Sangaralingham J, Chen H, Burnett JC Jr: Matrial natriuretic peptide and nitroglycerin in experimental acute hypertensive heart failure: differential actions of two cGMP activating therapeutics. J Am Heart Assoc 2014, 3:e000206.

doi:10.1186/2050-6511-16-S1-A3

Cite this article as: Burnett et al:: MANP: a novel particulate guanylyl cyclase $A$ receptor/cGMP activator for resistant hypertension:

preliminary first in human clinical trial results. BMC Pharmacology and Toxicology 2015 16(Suppl 1):A3.

Submit your next manuscript to BioMed Central and take full advantage of:

- Convenient online submission

- Thorough peer review

- No space constraints or color figure charges

- Immediate publication on acceptance

- Inclusion in PubMed, CAS, Scopus and Google Scholar

- Research which is freely available for redistribution

Submit your manuscript at www.biomedcentral.com/submit 